\title{
Home Garden Herbs and Medicinal Plants of Lefke, Cyprus
}

\author{
Mariam Gökçebağ ${ }^{1}$, Özge Özden ${ }^{\star}$ \\ ${ }^{1}$ Pir Pasa Sokak, no 33, Lefke, North Cyprus, TURKEY. \\ ${ }^{2}$ Department of Landscape Architecture, Faculty of Architecture, Near East University, Nicosia, North Cyprus, TURKEY.
}

\begin{abstract}
The objective of this study was to record edible herbs and fruits derived from home gardens in Lefke, Cyprus and in addition to determine the local residents' knowledge of medicinal uses of home growing plants within their home gardens. This study was performed in old Turkish Cypriot town Lefke, Cyprus. During the surveys between November 2016 and February 2017 the fruit and edible herb production was documented and standard interviews were performed with garden owners. A total number of nine herb and 20 fruit tree species were determined during the surveys. The most widely used herb was mint (Menhta spicata L.) followed by Origanum (Origanum majorona L.). Almost all home garden owners were aware of the health benefits of mint. The most widely used fruits were lemons (Citrus $x$ limon) and oranges (Citrus $x$ aurantium). The residents were aware of the Vitamin C content and health benefits of these fruits. However, almost all recorded fruit species were used for culinary purposes rather than their medicinal uses. Through this research, the role of Cypriot home gardens for traditionally grown herb and fruit plants and their effect on cultural-ecological socialization as well as their health benefits were determined.
\end{abstract}

Key words: Herbs, Medicinal, Traditional, Home Gardens, Rural, Cyprus.

\section{INTRODUCTION}

Mediterranean region landscapes resulted from the multifarious and primeval interaction of ecosystems and societies. ${ }^{1,2}$ It is known that Mediterranean region is among the richest regions in the world for wild and cultivated plant species. ${ }^{3}$ The rural landscape is a mosaic of natural and human shaped land uses which vary in size and arrangement. ${ }^{4}$ In rural areas home gardens have a great value in herb and medicinal plants. They are multispecies mixed agroecosystems. ${ }^{5}$ The term "home garden" refers to the traditional land use practices around a living house where several species of plants are planted and maintained by the members of the household which their products mainly consumed by house owners. ${ }^{6}$ It is known that home growing herbs and medicinal plants are socio-culturally important values for local communities. ${ }^{78}$ Particularly herbs and their use may be found in Chinese documents from as far as $3000 \mathrm{BC}$ and it is also important to underline that, herbs and spices have been gaining popularity since the end of World War II. It has becoming a hobby for many people not only to cook, but also grow them in home gardens for other uses. ${ }^{9}$ Cyprus lies at the eastern end of Mediterranean Basin, it is the third largest island of the Mediterranean Sea. ${ }^{10}$ It covers an area of $9,251 \mathrm{~km}^{2}$ and it is consisting of three geomorphological zones, the Troodos mountains, the Five Fingers Mountain range and Mesoarial plain which separates the two upland areas. Cyprus has a very diverse flora within the region. According to floristic surveys, there are around 2000 native and alien plant species, subspecies, varieties, forms and hybrids exists on the island. ${ }^{11,12,13}$ Although there are various
DOI: 10.5530/ijper.51.3s.64 Correspondence: Özge Özden, Department of Landscape Architecture, Faculty of Architecture, Near East University, Nicosia, north CYPRUS.

Phone no: 0090392680 2000

Email Id : ozge.fuller@neu. edu.tr 
ethnobotanical researches has been carried out on the island, research and documentation work on home gardens growing edible and medicinal plants are very limited. ${ }^{15,16,17}$ According to Lardons and Heinrich $(2013)^{14}$ medicinal uses of plants goes back to Ottoman period (1571-1878) which some of the local monasteries had dedicated places for the nursing of sick.In rural areas, Cypriot home gardens may occupy different positions such as the backyards, front-yards, site-yards and courtyards which have variable shapes, sizes and composition of plant species. They are mainly harboring supplementary fruits, vegetables and herbs for households. ${ }^{17}$ Home gardens in Cyprus are currently facing different threats mainly loss of interest on traditional gardening, loss of traditional knowledge on medicinal use of herbs and fruits. The objective of this study was to record edible herbs and fruits derived from home gardens in Lefke, Cyprus and in addition to determine the local residents' knowledge of medicinal uses of home growing plants within their home gardens.

\section{MATERIAL AND METHOD}

\section{Study Area}

The study was performed in Lefke town in Cyprus, which is situated north-west part of the island and overlooking Morphou Bay. The old name of the town was 'Lefka'. According to 2011 census the population of Lefke town was 3409 inhabitants. ${ }^{18}$ Lefke contains numerous historical houses that are in the CypriotOttoman architectural style. Most of these houses were built between 1900 and 1930. These historical houses have inner courtyards, reflecting the conservative, closed Islamic family life of the early $20^{\text {th }}$ century.Also Lefke has been historically important a copper mining town for Cyprus. It is known with citrus trees, walnut trees and ancient palm trees. Houses are surrounded by agro ecosystems and different variety of fruits trees.

\section{Climate}

Cyprus has a Mediterranean climate with hot dry summers and warm-rainy winters. Summer normally lasts from June to September and winter from November to March. The rainfalls mainly between October to March. In Lefke region the highest temperature in winter was $21.3^{\circ} \mathrm{C}$ and the lowest temperature was $4.7^{\circ} \mathrm{C}$ according to meteorology station records of 2012-2013. ${ }^{17}$

\section{Data collection}

Observation of home gardens and structured interviews of garden owners are the primary sources of data in this study. During the surveys in November 2016 - February 2017 a total number of 20 home gardens were visited and the fruit and edible herb production was documented. All fruit producing trees, shrubs and also herbs of the surveyed home gardens are identified and recorded to species level. While standard interviews were performed, participants provided permission to photograph and to collect some plant samples for identification. The questionnaire was mainly focused on home garden components and knowledge of culinary use and medicinal value of herbs and fruits that are cultivated by home owners in Lefke.

\section{RESULTS}

Traditional home gardens which were visited during the surveys were between the size of $40 \mathrm{~m}^{2}$ to $\max 250 \mathrm{~m}^{2}$ and they all had mixed cropping system which means mixture of herbs, ornamentals and fruit trees. A total number of nine herb and 20 fruit tree species were determined during the surveys. The most widely used herb was mint (Menbta spicata L.) followed by Origanum (Origanum majorona L.). Most of the determined herb species were consumed by the home owners for their medicinal value and as a spice in the kitchen (Table 1). According to survey results $60 \%$ of the garden owners

\begin{tabular}{|c|c|c|c|}
\hline \multicolumn{4}{|c|}{ Table 1: List of recorded herbs during the surveys and their use } \\
\hline Species Name & English Name & Family Name & Use \\
\hline Petroselinum crispum & Parsley & Apiaceae & Food \\
\hline Coriandrum sativumL. & Coriander & Apiaceae & Food \\
\hline Lavandula angustifolia Mill. & Lavender & Lamiaceae & Medicinal, Food, Ornamental \\
\hline Mentha spicata L. & Mint & Lamiaceae & Medicinal, Food, Ornamental \\
\hline Ocimum basilicum $L$ & Basil & Lamiaceae & Medicinal, Food, Ornamental \\
\hline Origanum majorana $L$. & Marjoram & Lamiaceae & Medicinal, Food, Ornamental \\
\hline Foeniculum vulgare & Fennel & Apiaceae & Medicinal, Food \\
\hline Rosemarinus officinalis & Rosemary & Lamiaceae & Medicinal, Food \\
\hline Melissa officinalis & Lemon Balm & Lamiaceae & Medicinal \\
\hline
\end{tabular}


were aware of the health benefits of the mint. Almost all home garden owners were aware of the health benefits of mint. They stated that they are using mint for treatment of digestion, irritable bowel syndrome and period pain treatment. Also, the home owners mentioned that they are using dried or green oregano for the treatment of coughing and chest infection. The most widely used fruits were lemons (Citrus $x$ limon) and oranges (Citrus $x$ aurantium). The residents were aware of the Vitamin C content and health benefits of these fruits. Survey results indicated that $65 \%$ of the home owners were using lemon for its ' health benefits. Most of the home owners were using lemon for cold treatment and balancing blood pressure. Also, they emphasised that, most of the Lefke residents consuming walnut for brain functioning. In general, most of the interviewers emphasised the fact that fruits are rich vitamin and mineral resources. However, almost all recorded fruit species were used for culinary purposes rather than their medicinal uses.

\section{CONCLUSION}

Traditional knowledge of growing herbs has significant positive effects for human well-being and also playing an active role in biodiversity conservation within the rural areas. ${ }^{8,12}$ It is crucial to understand the medical traditions in order to create sustainable living environment. Through this research, the role of Cypriot home gardens for traditionally grown herb and fruit plants and their effect on cultural-ecological socialization as well as their health benefits were determined. The pattern of traditional use of edible plants for medicinal value has been decline, but this research has shown that traditional use of edible plants in home gardens for medicinal and kitchen use purposes still alive in Lefke and knowledge has been shared between older and younger generations. In addition, this study concludes the botanical richness of home gardens in Cyprus, particularly the richness of edible plants. Home gardens are important sites for in-situ conservation of local edible plant species, therefore it should be investigated and conserved.

\section{ACKNOWLEDGEMENT}

Authors would like to thanks Dr Wayne J Fuller (Near East University) for comments and language proof reading on earlier drafts of the manuscript. Additionally, the authors would like to thank the participants who allowed us to survey their gardens.

\section{CONFLICT OF INTEREST}

None

\section{ABBREVIATION USED}

km: kilometre; BC: Before Christ; ${ }^{\circ} \mathrm{C}$ : Centigrade.

\section{REFERENCES}

1. Geri F, Amici V, Rocchini D. Human activity impact on the heterogeneity of Mediterranean Landscape. Applied Geography, 2010;30(3):370-9.

2. Sirami C, Nespoulous A, Cheylan JP, Marty P, Hvenegaard GT, Geniez P, et al. Long-term anthropogenic and ecological dynamics of a Mediterranean landscape: Impacts on multiple taxa. Landscape and Urban Planning. 2010;96(4):214-23.

3. Domina G, Pasquale M, Vivienne S, Francesco MR. Vascular flora evaluation in the major Mediterranean islands. Biodiversity Journal, 2012;3(4):337-42.

4. Zaizhi Z. Landscape change in a rural area in China. Landscape and Urban Planning, 1999;47(1-2):1-9.

5. Moreno-Black G, Somnasang P, Thamathawan S. Cultivating continuity and creating change: women`s home garden practices in north-eastern Thailand. Agriculture and Human Values, 1996;13(3):3-11.

6. Mekonen T, Gidy M, Kelbessa E. Ethnobotanical study of home garden plants in Sebeta-Awas District of Oromia Region of Ethiopia to assess use, species diversity and management practices. Journal of Ethno boil Ethno med. 2015;11(1):64.

7. Rahaman MM, Haider MZ, Chakraborty M. Contribution of home garden to household economy in rural areas of Bangladesh. Asia-Pacific Journal of Rural Development. 2015;25(1):49-58.

8. Torri MC, Hollenberg D. Therapeutic uses of edible plants in Bangalore city, India: combining health with cooking practices through home herbal gardens. Environ Dev Sustain. 2012;14(3):303-19.

9. Kybal J, Kaplica J. Herbs and Spices, Harveys Bookshop Ltd. Magna Books; 1995;224 pages

10. Meikle RD. Flora of Cyprus, Volume Two, Published by the Bentham - Moxon Trust, Royal Botanic Gardens, Kew, 1985;1969 pages.

11. Medail F, Quezel P. Biodiversity Hotspots in the Mediterranean Basin: Setting Global Conservation Priorities. Conservation Biology. 1999;13(6):1510-3.

12. Hadjikyriakou GN. Aromatic and Spicy Plants in Cyprus from Antiquity to the Present Day.Bank of Cyprus Cultural Foundation, Nicosia. 2007;441 pages.

13. Özden Ö, Ciesla WM, Fuller WJ, Hodgson DJ. Butterfly diversity in Mediterranean islands and in Pentadaktylos Pinusbrutia forests of Cyprus. Biodiversity and Conservation. 2008;17(12):2821-32.

14. Lardos $A$, Heinrich $M$. Continuity and change in medicinal plant use: the example of monasteries on Cyprus and historical iatrosphia texts. Journal of Ethnopharmacology, 2013;50(1):202-14. doi: 10.1016/j.jep.2013.08.026.

15. Della A, Paraskeva-Hadjichambi D, Hadjichambis A. An ethnobotanical survey of wild edible plants of Paphos and Larnaca countryside of Cyprus. Journal of Ethnobiology and Ethnomedicine, 2006;2(1):34. DOI: 10.1186/1746-4269-2-34.

16. Ciftcioglu GC. Sustainable wild- collection of medicinal and edible plants in Lefke region of North Cyprus. Agro forest Syst. 2015;89(5):917-31.

17. Özersoy DA, Fuller ÖÖ. The comparative value of edible plants in home gardens of a Cypriot rural village. Journal of International Scientific Publications. 2016;10:360-4.

18. DPÖ. State Planning Organization 2013, Turkish Republic of Northern Cyprus, State Planning Organization, Statistics and Research Department, 2013;313 pages. 
PICTORIAL ABSTRACT

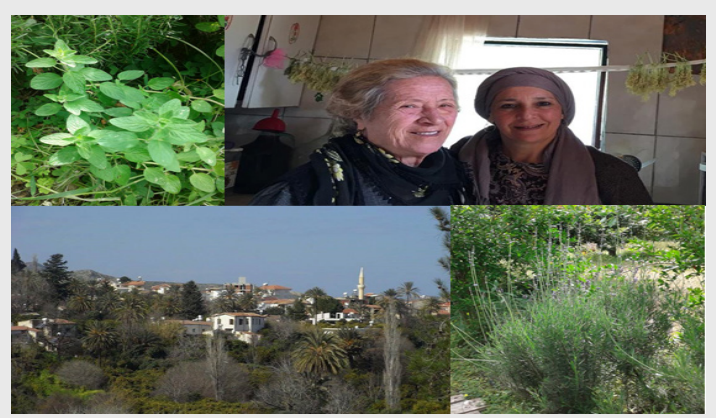

\section{SUMMARY}

- Record edible herbs and fruits derived from home gardens in Lefke, Cyprus

- A total number of nine herb and twenty fruit tree species were determined.

- Most used herb was mint and origanum.

- The most widely used fruits were lemons and oranges.

- Most fruits were grown for culinary purposes.

\section{ABOUT AUTHORS}

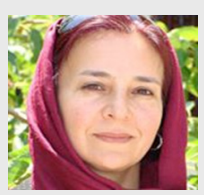

Mariam Gokcebag is a Herbalist, specializing in medicinal herbs. She has attended many workshops and given seminars, She has wide variety of herbs within her own garden if Lefke, She is the author of a book called 'Healthy Living in Cyprus'.

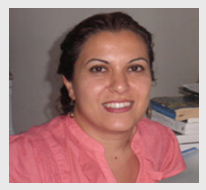

Assoc. Prof. Dr. Ozge Ozden is an ecologist who studied a PhD at Exeter University on the subject of 'Biodiversity`. She has published many scientific papers related to the subject of 'biodiversity of Cyprus `. Currently she has interest on biodiversity of traditional home gardens in Cypriot rural landscapes. She is Head of Department of Landscape Architecture at Near East University, Cyprus.

Cite this article: Gökçebag M, Özden Ö. Home Garden Herbs and Medicinal Plants of Lefke, Cyprus. Indian J of Pharmaceutical Education and Research. 2017;51(3)Suppl:S441-44. 